\title{
PLACEMAKING SEBAGAI STRATEGI REVITALISASI KAWASAN Studi Kasus : Kawasan Pecinan Kota Makassar
}

\author{
Sri Wahyuni \\ Dosen Prodi Arsitektur, Fakultas Teknik Universitas Muhammadiyah Makassar \\ swahyunimarzuki@unismuh.ac.id
}

\begin{abstract}
Pecinan Makassar merupakan bagian dari perkembangan sejarah kota Makassar. Pecinan Makassar terletak di pusat kota dekat dengan pelabuhan sehingga menjadi awal kegiatan perdagangan dan jasa. Letaknya yang strategis menjadikan kawasan sebagai pusat perdagangan yang vital pada zaman kolonial. Namun sejalan dengan perkembangan zaman, Pecinan Makassar mengalami penurunan kualitas fisik, aktifitas ekonomi, dan sosial budaya yang mengakibatkan pudarnya identitas pecinan Makassar. Secara perlahan kawasan mulai ditinggalkan dan kegiatan ekonomi berpindah ke pusat perdagangan baru di luar pecinan. Oleh karenanya kawasan membutuhkan upaya penataan untuk mengembalikan vitalitas pecinan yang kontekstual dengan masa kini tanpa menghilangkan jejak sejarah kawasan.Pembahasan ini bertujuan untuk merumuskan strategi perancangan dalam mempertahankan identitas kawasan pecinan sebagai kawasan perdagangan yang unik dan meningkatkan kualitas lingkungan dengan revitalisasi kawasan. Penurunan kualitas fisik, penurunan kegiatan ekonomi dan sosial budaya pada kawasan Pecinan Makassar diselesaikan dengan strategi penciptaan kembali makna (identitas) kawasan melalui pendekatan placemaking.Langkah-langkah dalam upaya revitalisasi kawasan dilakukan dengan mengidentifikasi dan menganalisis komponen fisik, fungsi dan aktifitas, serta citra budaya kawasan pecinan. Hasil dari analisis kemudian menjadi dasar panduan yang selanjutnya diuraikan dalam strategi pengembangan kawasan untuk memberi gambaran mengenai arahan penataan Pecinan Makassar.
\end{abstract}

Kata kunci: kawasan pecinan, Makassar, revitalisasi, placemaking.

\section{PENDAHULUAN}

Laju perkembangan Kota Makassar membawa dampak yang cukup besar terhadap kawasan pecinan ${ }^{1}$ terutama pada kegiatan ekonomi masyarakat Cina. Awal tahun 1990, pemerintah mengadakan perluasan pelabuhan yang mempengaruhi kelancaran transportasi barang-barang dagangan antar pulau. Kegiatan ekonomi kota yang meningkat, menjadi pendorong munculnya pusat perdagangan baru yang lebih lengkap dan modern. Hal ini menciptakan pusat-pusat ekonomi (aktifitas perdagangan) lebih menyebar ke seluruh kota atau tidak terkonsentrasi hanya pada satu kawasan

Pusat ekonomi yang tersebar mengakibatkan kawasan pecinan ${ }^{2}$ tidak lagi

\footnotetext{
Kawasan ini merupakan bagian dari sejarah perkembangan Kota Makassar yaitu sebagai embrio pertumbuhan serta perkembangan Kota Makassar.

Pecinan Makassar terletak pada kawasan perdagangan dan jasa di pusat kota lama. Letaknya yang strategis menyebabkan kawasan ini menjadi kawasan yang vital pada zamannya yaitu sebagai pusat perdagangan yang ramai. Kawasan ini juga terletak dekat dengan pelabuhan laut Kota Makassar, Pelabuhan Soekarno-Hatta. Secara historis, pedagang
}

menjadi pusat perdagangan dalam kota. Kawasan Pecinan Makassar telah mengalami penurunan kinerja fisik dan fungsi yang merupakan identitas dari suatu kawasan pecinan. Hingga saat ini kawasan Pecinan Makassar masih dapat ditandai oleh peninggalan jejak fisik, aktifitas perdagangan, dan kehidupan sosial warganya yang mengelompok. Kualitas lingkungan fisik dan non fisik yang menurun mendorong pemerintah kota Makassar menetapkan perencanaan dan perancangan kawasan ini sebagai kawasan objek wisata kota mengingat kawasan telah ada sejak jaman kolonial. Oleh sebab itu perlu penanganan berupa revitalisasi kawasan sebagai upaya mempertahankan identitas kawasan melalui usulan strategi placemaking. Tindakan revitalisasi tidak hanya sekedar beautification tetapi juga menghidupkan aktifitas perekonomian kawasan disesuaikan dengan kondisi perekonomian masa kini dan masa yang akan datang.

memasukkan barang-barang perdagangan melalui pelabuhan laut ini dan disalurkan ke kawasan perdagangan, salah satunya yaitu ke kawasan Pecinan. 
Kajian menggunakan pendekatan penciptaan tempat (placemaking) yang didorong oleh ekonomi lokal sebagai strategi dan isi dari revitalisasi kawasan Pecinan Makassar. Pendekatan placemaking merupakan pendekatan perancangan kawasan yang memiliki dimensi lebih hasil asimilasi dari elemen fisik dan non-fisik, sehingga hasil kajian ini dapat menjadi jiwa dari wujud revitalisasi di kawasan Pecinan Makassar.

\section{Placemaking dalam Revitalisasi Kawasan Pecinan}

Revitalisasi kawasan mengakomodasi perubahan dengan sikap yang sensitif dan pantas dalam mempreservasi karakter dari lokalitas setempat, sejalan dan mengijinkan dengan perubahan ekonomi yang diperlukan (Tiesdell dkk., 1996). Dalam revitalisasi kawasan Pecinan, obyek revitalisasi memiliki signifikansi budayanya sendiri. Signifikansi budaya ini kemudian merujuk dari piagam Burra Charter (1992) yang berlaku secara internasional.

Dalam Piagam Burra Charter, kawasan yang memiliki signifikansi budaya, yaitu memiliki nilai-nilai estetika, kesejarahan, keilmuan dan nilai sosial masa lalu, masa sekarang dan masa yang akan datang (Burra Charter, 1992). Melalui pendekatan tersebut, diharapkan revitalisasi dapat mempertahankan atau melindungi signifikansi budaya sebuah tempat atau kawasan dengan tetap memperhatikan keamanan, pemeliharaan dan masa depannya. Pelestarian sebagai bagian dari revitalisasi didasarkan pada sebuah penghargaan pada keadaan eksisting dan sesedikit mungkin menggunakan intervensi fisik. Hal tersebut juga dilakukan tanpa mengurangi atau melemahkan signifikansi budaya yang dimilikinya. Pelestarian sebuah tempat harus pula memperhatikan seluruh aspek dari signifikasi budaya tanpa merusak tatanan yang ada.

Dalam merevitalisasi kawasan pecinan digunakan satu pendekatan yang menjadi strategi utama untuk menghidupkan atau menguatkan makna/identitas kawasan. Placemaking merupakan suatu pendekatan yang dapat diterapkan untuk menguatkan keberadaan suatu kawasan dimana tetap sejalan dengan strategi-strategi revitalisasi lainnya. Terdapat 3 (tiga) komponen placemaking yang dapat mendukung kesuksesan sebuah tempat, yaitu: fisik, fungsi dan aktifitas, dan citra/budaya. Komponen fisik kemudian dibahas kedalam elemenelemen fisik diantaranya bentuk dan tata massa bangunan, intensitas bangunan, sirkulasi kendaraan dan parkir, sirkulasi pejalan, ruang terbuka, dan preservasi bangunan. Penciptaan fungsi dan aktivitas dibahas berdasarkan fungsi dan aktivitas baik utama maupun pendukung dalam kawasan. Sedangkan penciptaan komponen citra/budaya suatu kawasan dapat mengacu dari Piagam Burra Charter (1992) yang membahas mengenai pelestarian pada kawasan yang memiliki signifikansi budaya. Kawasan yang memiliki signifikansi budaya memiliki nilai estetika, kesejarahan, keilmuan, dan sosial.

Tabel 1.Hubungan Strategi Revitalisasi, Komponen Placemaking dan Elemen Rancang Kota

\begin{tabular}{ccc}
\hline $\begin{array}{c}\text { Strategi } \\
\text { Revitalisasi }\end{array}$ & $\begin{array}{c}\text { Komponen } \\
\text { Placemaking }\end{array}$ & $\begin{array}{c}\text { Elemen Rancang } \\
\text { Kota }\end{array}$ \\
\hline Strategi & Fisik & $\begin{array}{c}\text { Intensitas } \\
\text { bangunan } \\
\text { Fisik }\end{array}$ \\
& & $\begin{array}{c}\text { Tata massa } \\
\text { bangunan } \\
\text { Sirkulasi dan parkir } \\
\text { Sirkulasi pejalan } \\
\text { kaki } \\
\text { Konservasi }\end{array}$ \\
\hline Strategi & Aktivitas & $\begin{array}{c}\text { Fungsi/penggunaan } \\
\text { lahan }\end{array}$ \\
Ekonomi & & Aktifitas pendukung \\
\hline Strategi & Citra/budaya & Aktifitas \\
Sosial & & \\
\hline Sumber: & & \\
\hline
\end{tabular}

Sumber : Montgomerry (1998), Carmona (2003), dan analisis.

\section{GAMBARAN UMUM KAWASAN}

Kawasan pecinan yang termasuk dalam Kawasan Pusat Kota Lama Makassar. Secara geografis, Kawasan pecinan terletak di pantai bagian Utara Kota Makassar. Wilayah studi terletak pada tiga kelurahan yaitu Kelurahan Melayu Baru, Kelurahan Ende, Kelurahan Pattunuang dan termasuk juga dalam wilayah Kecamatan Wajo dengan luas keseluruhan $\pm 7 \mathrm{Ha}$. Luas wilayah masingmasing kelurahan yaitu Kelurahan Ende $0,16 \mathrm{~km}^{2}$, Kelurahan Pattunuang $0,21 \mathrm{~km}^{2}$ dan Kelurahan Melayu Baru 0,07 km² 
dengan tingkat kepadatan penduduk pada kawasan studi sebesar 364 jiwa/ha.

Masyarakat yang mendiami kawasan tersebut sebagian besar merupakan etnis Cina. Masyarakat Cina dalam kawasan sebagian besar memeluk agama Budha yaitu $\pm 80 \%$, sehingga kehidupan religi mereka dipusatkan pada kegiatan ibadah di dalam klenteng. Klenteng selain berfungsi sebagai tempat berdoa, memuja dan melakukan aktifitas keagamaan lainnya juga berfungsi sebagai pusat kegiatan sosial kemasyarakatan.

Kawasan Pecinan di Makassar memiliki aksesibilitas yang mudah dicapai, baik melalui darat maupun melalui laut. Seperti Kawasan pecinan pada umumnya, kawasan dibentuk oleh pola grid sebagai jalan yang memiliki lebar antara $3 \mathrm{~m}-10$ $\mathrm{m}$, dimana bangunan saling berhadapan menimbulkan ruang kota yang berbentuk lorong sehingga interaksi sosial terjadi di jalan (corridor space). Kawasan dapat diakses menggunakan kendaraan pribadi sekitar 5 menit dari Pelabuhan Soekarno Hatta dan dari titik nol Kota Makassar (Karebosi). Kawasan juga dapat diakses oleh pejalan. Akan tetapi sirkulasi pejalan pada kawasan tidak terdefinisi dengan baik karena digunakan sebagai tempat parkir kendaraan pribadi.

Kondisi pecinan saat ini memiliki kepadatan bangunan yang cukup tinggi dan tidak memiliki ruang terbuka. Aktifitas keseharian masyarakat yang sebagian besar etnis Cina adalah berdagang memberikan pengaruh terhadap jenis hunian yang mereka gunakan. $\mathrm{Di}$ sepanjang ruas jalan terutama jalan utama merupakan deretan bangunan rumah toko. Di belakang deretan pertokoan terdapat permukiman padat di daerah kantong dalam blok kawasan. Permukiman dapat diakses melalui gang-gang kecil yang terdapat diantara bangunan-bangunan di koridor jalan. Pada beberapa akses masuk gang, terdapat pintu gerbang ke arah jalan besar yang sewaktu-waktu dapat ditutup.
ANALISIS KONDISI EKSISTING KAWASAN PECINAN MAKASSAR Analisis Makna/budaya dalam Kawasan
Identifikasi signifikansi budaya membantu memperkirakan nilai sebuah

tempat yang mampu menjelaskan dan menerangkan kejadian masa lalu, memperkaya masa kini, dan dianggap mampu menjadi sesuatu yang berharga bagi masa yang akan datang. Nilai-nilai tersebut saling mendukung seperti gaya arsitektural yang memiliki aspek historis dan estetika (Burra Charter, 1992). Dalam Burra Charter (1992), ada empat nilai utama yang dapat digunakan untuk menilai adanya signifikansi budaya pada suatu kawasan. Keempat nilai tersebut adalah :

\section{Nilai estetika}

Nilai estetika berkaitan dengan fisik bangunan pada kawasan pecinan. Kawasan pecinan memiliki beberapa bangunan yang khas yaitu klenteng/vihara, bangunan penyimpanan abu yang berarsitektur cina dan bangunan mesjid yang dibangun pada zaman kolonial. Dilihat dari segi estetika, bangunanbangunan tersebut memiliki elemen arsitektural yang unik dan menarik. Hal tersebut dapat dilihat langsung pada tampulan bangunan dan fasad bangunannya, dimana bagian muka bangunan merupakan elemen arsitektur yang paling penting karena mampu mengkomunikasikan fungsi dan makna dari bangunan. Fasad dapat mencerminkan situasi budaya ketika bangunan tersebut dibangun dan keadaan penghuni yang menempatinya, serta memberikan identitas kolektif dari suatu komunitas (Krier, 1979).

\section{Nilai kesejarahan}

Terkait dengan nilai kesejarahan, kampung Pecinan Makassar memiliki sejarah dalam pembentukannya. Arsitektur Oriental berkembang setelah masyarakat Cina melakukan aktifitas perdagangan dengan didasari atas Wijkenstelsel yaitu sebuah undang-undang yang mengatur kehidupan kolonial yang pada dasarnya memisahkan hunian kelompok etnis dengan para kelompok pribumi. Sehingga area blok-blok masyarakat Cina sering disebut dengan kampung pecinan.

Pada skala makro, kawasan pecinan merupakan salah satu kawasan yang berperan dalam pengembangan kota Makassar. Tidak hanya dalam hal perdagangan tetapi juga merupakan kawasan yang dihuni oleh mayoritas etnis 
Cina yang pada saat itu merupakan permukiman yang memisahkan antara permukiman pribumi dan pemerintah kolonial (permukiman Eropa). Sedangkan pada skala mikro, kawasan pecinan merupakan sentra kawasan perdagangan yang berupa jejeran rumah toko dan beberapa hunian yang bergaya kolonial. Suasana lingkungannya yang khas diperkuat dengan kehadiran kelenteng sebagai pusat ibadah dan sosial serta bentuk-bentuk bangunan yang mudah ditengarai. Kawasan pecinan mempunyai karakteristik dekat dengan pasar dan Pelabuhan yang menjadi tempat masuknya barang-barang dari negara lain.

\section{Nilai Keilmuan}

Dari segi keilmuan, kawasan pecinan merupakan salah satu kawasan yang selalu ada di hampir semua kota-kota di Indonesia. Hampir seluruh kota di Indonesia memiliki kawasan pecinan yang memiliki fungsi sebagai kawasan sentra perdagangan dan permukiman bagi etnis Cina. Pada umumnya kawasan ini memiliki pembagian zona yang teratur dan terencana dengan baik, yakni lantai dasar digunakan sebagai area komersil sedangkan untuk area lantai atas digunakan sebagai hunian. Kawasan ini menarik untuk diteliti karena merupakan kawasan yang sudah mempunyai karakter dan bernilai historikal sebab dibangun pada zaman kolonial dulu. Kawasan Pecinan Makassar mengalami perkembangan dari masa ke masa. Beberapa perubahan terjadi pada kawasan, antara lain berupa perubahan fungsi dari hunian menjadi kawasan perdagangan yang semakin tidak terkendali yang ditandai dengan semakin menjamurnya rumah-rumah toko modern. Umumnya kawasan pecinan memiliki pola morfologi yang serupa dengan kota di Cina dengan digunakannya pola pusat kotapermukiman dan pasar-klenteng.

\section{Nilai sosial}

Pada kawasan pecinan, kegiatan bersosialisasi tidak hanya dilakukan pada tempat-tempat ibadah seperti klenteng dan mesjid yang terdapat dalam kawasan tetapi juga pada pasar pagi yang terletak di Jalan Bacan. Klenteng dan masjid yang terdapat dalam kawasan sebagai tempat ibadah tentunya juga memiliki makna sosial yang mendalam bagi masyarakatnya karena bangunan-bangunan tersebut selain menjadi tempat bersilaturahmi juga menimbulkan rasa kepemilikan oleh masyarakat secara spiritual. Sedangkan pasar Bacan memiliki skala pelayanan hanya pada kawasan pecinan saja sehingga menjadi trademark tersendiri bagi kawasan tersebut.

\section{Analisis Fungsi dan Aktifitas dalam Kawasan Perancangan}

Kondisi eksisting fungsi/peruntukan bangunan yang ada di dalam kawasan studi secara umum didominasi oleh fungsi perdagangan (ruko). Fungsi-fungsi lain seperti jasa, pendidikan, dan peribadatan umumnya terdapat pada jalur-jalur utama dalam kawasan. Fungsi hunian terdapat pada kantung-kantung permukiman yang berada di belakang blok-blok bangunan yang berderet di sepanjang Jalan Bacan dan Jalan Lembeh. Di dalam kawasan studi, fungsi ruang terbuka publik yang bersifat aktif (wadah aktifitas dan interaksi masyarakat) jumlahnya sangat minim, bahkan hampir tidak ada. Selama ini masyarakat menggunakan jalan sebagai ruang sosial bersama. Sedangkan ruang terbuka yang bersifat pasif (ruang terbuka hijau untuk fungsi ekologis) terlihat tidak ada. Orientasi kegiatan masyarakat yang ada lebih banyak berorientasi kepada fungsi-fungsi kegiatan yang berada di sepanjang tepi koridor jalan.

Aktifitas pada setiap ruas jalan dalam kawasan tidak sama. Hal ini dikarenakan pada beberapa ruas jalan ada yang lebih didominasi oleh fungsi perdagangan dan ada pula yang lebih didominasi oleh fungsi hunian. Pada ruas jalan utama, lebih didominasi oleh aktifitas perdagangan yang cukup ramai. Karakteristik fungsi dan kegiatan yang berada di sepanjang tepi koridor dalam kawasan memiliki rentang waktu kegiatan yang tidak terlalu panjang. Rata-rata rentang waktu yang ada dimulai sejak pukul 07.00 pagi hingga 17.00 (untuk aktifitas perdagangan). Pada Jalan Bacan, kegiatan jual beli pasar tradisional dimulai dari pukul 05.00 pagi hingga pukul 12.00 siang. Dari hasil pengamatan lapangan, 
aktifitas yang terdapat di koridor-koridor jalan pada waktu malam hari tidak hidup termasuk aktifitas perdagangan sehingga dimalam hari kawasan ini menjadi 'mati'.

\section{Analisis Fisik Kawasan}

Revitalisasi kawasan pecinan yang dilakukan berada dalam lingkup ruang kota. Maka semua strategi dan pendekatan yang dilakukan akan selalu berkaitan dan mengintervensi elemen-elemen dalam ruang kotanya. Elemen kota yang diintervensi adalah elemen rancang kota Shirvani (1985) yaitu tata guna lahan, intensitas bangunan, tata massa bangunan, ruang terbuka, sirkulasi dan parkir, sirkulasi pejalan, konservasi dan aktifitas pendukung. Elemen-elemen tersebut tidak hanya termasuk dalam elemen fisik suatu kawasan, tetapi juga dapat mendukung revitalisasi ekonomi dari elemen fungsi dan aktifitasnya serta revitalisasi sosial dari pengadaan ruang sosialnya.

\section{Tata Massa Bangunan}

Tata massa bangunan eksisting yang ada pada kawasan terdiri dari jejeran rukoruko dengan beberapa titik kantong permukiman. Tata permukiman dibangun secara berkelompok dengan mengikuti ruas jalan yang ada. Akan tetapi pembangunan yang dilakukan tidak memperhatikan aspek kondisi bangunan dan lingkungan yang telah ada sehingga mendorong terbentuknya bangunanbangunan yang acak dan lebih modern. Kawasan sebagian besar didominasi oleh susunan massa-massa bangunan deret berjejer di dua sisi koridor jalan (luas dasar bangunan kurang dari $50 \mathrm{~m}^{2}$ ). Kondisi ini mengakibatkan minimnya akan ketersediaan ruang terbuka untuk fungsi sirkulasi, sosial serta untuk jaringan utilitas.

Tipologi bangunan eksisting dalam kawasan perancangan dapat menjadi dasar bentukan fisik bagi fungsi yang akan dikembangkan dan menjadi dasar pertimbangan untuk menentukan bangunan yang dapat dipertahankan ataupun tidak dapat dipertahankan. Dari ciri fisik fasad dan atap dapat dikategorikan menjadi beberapa tipe bangunan. Berdasarkan pengamatan lapangan, tipologi bangunan pada kawasan studi terbagi kedalam beberapa 7 (tujuh) tipe sebagai berikut :

Tabel 2. Tipologi Bangunan Dalam Kawasan Studi

\begin{tabular}{|c|c|c|}
\hline Tipe & Tipologi Ruko & Keterangan \\
\hline A & & 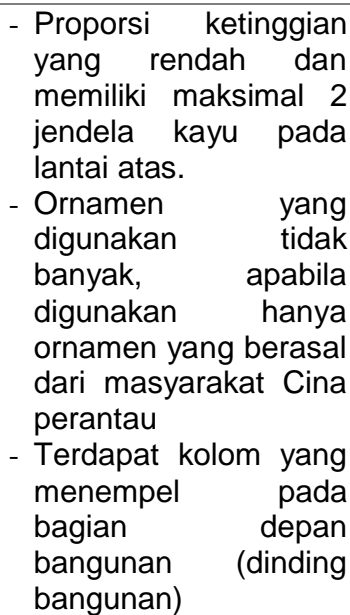 \\
\hline B & $\begin{array}{l}\text { (Permulaz } \\
1900)\end{array}$ & $\begin{array}{l}\text { - Memiliki } 2 \text { jendela } \\
\text { pada lantai atas } \\
\text { - Jendela-jendela tetap } \\
\text { menggunakan jendela } \\
\text { kayu walaupun pintu } \\
\text { pada lantai bawah } \\
\text { telah menggunakan } \\
\text { pintu besi } \\
\text { - Tidak begitu banyak } \\
\text { menggunakan } \\
\text { ornamen. }\end{array}$ \\
\hline C & Gay & $\begin{array}{l}\text { - Terdapat gevel pada } \\
\text { tampak depan } \\
\text { bangunan } \\
\text { - Penggunaan flat roof, } \\
\text { tower, dan bentuk } \\
\text { kubus. } \\
\text { - Dormer, merupakan } \\
\text { jendela atap yang } \\
\text { menjadi komponen } \\
\text { pencahayaan dan } \\
\text { sirkulasi penghawaan. } \\
\text { - Ditandai oleh } \\
\text { konstruksi batu bata } \\
\text { dan batu dengan } \\
\text { penampilan bulat. }\end{array}$ \\
\hline D & Gaya Modern & $\begin{array}{l}\text { - Menggunakan } \\
\text { material modern } \\
\text { seperti penggunaan } \\
\text { kaca yang lebih } \\
\text { banyak } \\
\text { - Penyederhanaan } \\
\text { tembok hiasan pada } \\
\text { bangunan dengan } \\
\text { menggunakan alat } \\
\text { penghalang matahari } \\
\text { dan ventilasi } \\
\text { - Umumnya mengguna }\end{array}$ \\
\hline
\end{tabular}




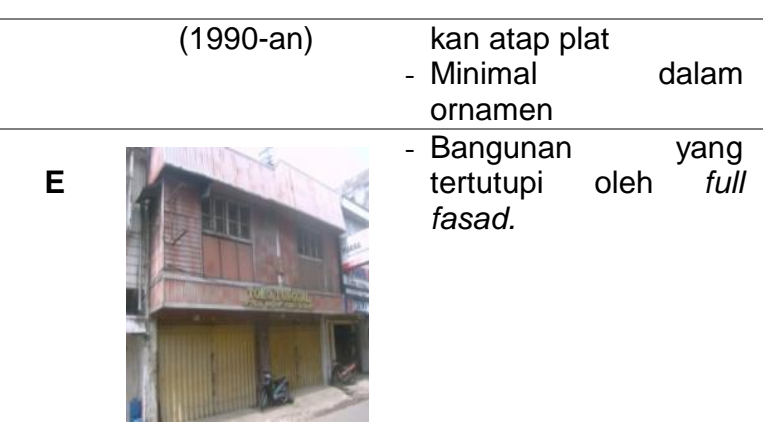

Full Fasad

$\mathbf{F}$

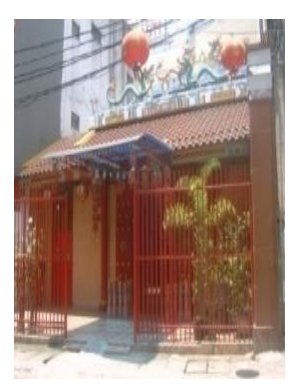

Bangunan yang menggunakan langgam Pecinan
Bangunan mengguna kan ornamen Cina. Dapat dilihat pada puncak atap dan lampion pada yang tergantung pada fasad bangunan.

Bangunan dengan ornamen Cina ini dapat dilihat pada bangunan dengan fungsi peribadatan bagi etnis Cina, seperti vihara/klenteng, dan tempat persemayaman abu.

Sumber : Chinatown Historic District dan analisis, 2015

\section{Intensitas Bangunan}

Intensitas bangunan dalam kawasan sangat penting untuk diperhatikan karena berpengaruh pada estetika bangunan dan lingkungan sekitarnya. Pada kawasan, tingkat Koefisien Dasar Bangunan (KDB) dan Koefisien Lantai Bangunan (KLB) terbagi ke dalam 2 zona, yaitu zona kawasan non perdagangan dan jasa dan zona pada ruas jalan komersil. Pada zona kawasan non perdagangan dan jasa KDB $60 \%$, KLB 1,8 dengan ketinggian bangunan umumnya $1-2$ lantai. Sedangkan pada zona ruas jalan komersil, KDB bervariasi antara $40-75 \%$, KLB 1,5 - 3,2 dengan ketinggian bangunan 1 -8 lantai.

Bangunan dengan ketinggian 1 hingga 2 lantai umumnya terdapat pada kawasan kantung permukiman, sedangkan ketinggian bangunan 1 hingga 3 lantai terdapat pada kawasan tepi koridor jalan dengan fungsi hunian-komersil, dan 2 hingga 7 lantai untuk fungsi komersil, mixed use, peribadatan, dan jasa. Berdasarkan kondisi tersebut, maka garis langit (skyline) kawasan menjadi rendah pada daerah kantung permukiman dan meninggi pada daerah tepi koridor jalan.

\section{Sirkulasi dan Parkir}

Kawasan Pecinan yang termasuk dalam tiga Kelurahan ini dapat dicapai dengan mudah oleh kendaraan bermotor dan pejalan, melalui ruas koridor Jl. Nusantara tembus ke JI. Sulawesi, Jl. Jend. Ahmad Yani, dan JI. Sangir. Kemudahan tersebut didukung pula oleh tersedianya beberapa moda angkutan umum yang melintasi ruas koridor $\mathrm{Jl}$. Sulawesi, JI. Sangir, dan JI. Jend. Ahmad Yani. Untuk masuk ke dalam kawasan kantung permukiman, jalur sirkulasi yang ada hanya dapat diakses oleh kendaraan beroda dua dan pejalan. Selain itu, minimnya keberadaan tempat parkir dari fungsi-fungsi perdagangan, jasa, dan hunian pada kawasan mengakibatkan parkir kendaraan ditempatkan di bagian tepi badan jalan (on street parking).

Persoalan sirkulasi pejalan (pedestrian) yang tidak menerus masih tidak mendukung koridor ini bagi penggunanya. Lebar ruang untuk jalur pejalan yaitu $1 \mathrm{~m}$ hingga $1,5 \mathrm{~m}$ pada bangunan. Akan tetapi banyaknya perbedaan level ketinggian mengakibatkan pejalan justru merasa lebih baik menggunakan bahu jalan, walaupun tidak ternaungi oleh vegetasi.

\section{Ruang Terbuka Koridor}

Ruang terbuka yang tersedia dalam kawasan adalah ruang terbuka publik koridor berupa jalan. Ruang terbuka koridor dalam kawasan merupakan jalan-jalan utama dan gang dalam kantong pemukiman. Baik secara fisik maupun fungsi, ruang terbuka publik koridor berupa jalan atau gang merupakan salah satu elemen pembentuk karakter yang tidak dapat dilepaskan dari citra kawasan permukiman Pecinan. Jalan atau gang telah menjadi 'nyawa' bagi penduduk pada kawasan permukiman etnis Cina. Selain sebagai jalur sirkulasi, koridor jalan juga berfungsi sebagai tempat berinteraksi dan bersosialisasi warga masyarakat.

Pada kawasan juga terdapat ruang-ruang yang berpotensi sebagai ruang terbuka publik. Ruang-ruang di belakang blok-blok bangunan berpotensi untuk dikembangkan sebagai ruang terbuka publik. Kondisi bangunannya yang tidak terawat dan ruang sekitar bangunan yang tidak difungsikan (mati) menjadikan ruang-ruang tersebut dapat dilihat sebagai suatu potensi yang dapat mewadahi aktifitas publik. Walaupun ruang tersebut statusnya dimiliki oleh privat dan tidak dapat 
diakses oleh publik, tetapi kerjasama antara stakeholder (pemilik bangunan dan pemerintah) yang saling menguntungkan dapat meningkatkan kualitas ruang tersebut sebagai ruang terbuka publik. Minimnya keberadaan ruang terbuka publik sebagai sarana untuk berinteraksi sosial telah mengakibatkan jaringan hubungan sosial yang dapat mempererat kebersamaan warga menjadi berkurang.

Strategi penataan terhadap ruang terbuka publik pada kawasan perlu dilakukan untuk mendukung kenyamanan dan kemudahan penggunanya untuk beraktifitas dan mengakses semua fungsi yang ada. Penataan dilakukan pada koridor ruang jalan yang menjadi tempat bertemunya warga dan menjadi ruang bagi perayaan budaya kawasan pecinan. Hal tersebut sekaligus menjadi penyatu bagi fungsi-fungsi yang akan dikembangkan nantinya melalui penerusan akses kesemua fungsi.

\section{Preservasi}

Pada kawasan Pecinan terdapat beberapa bangunan bersejarah, antara lain : Klenteng Xian Ma yang dibangun pada masa Dinasti Qing (1864), bangunan dengan arsitektur Cina yaitu yayasan Marga Thoeng tempat persemayaman abu jenazah, Masjid As-Sa'id yang berdiri sejak tahun 1907, dan beberapa bangunan bergaya kolonial.

Keberadaan bangunan-bangunan tersebut memberikan nuansa tersendiri karena dapat memperkaya kekayaan arsitektural pada kawasan. Keberadaan bangunan tersebut dapat dijadikan sebagai daya tarik wisata pada kawasan dengan menawarkan konsep yang sesuai dengan karakteristik kawasan sebagai kawasan Pecinan.

\section{STRATEGI PENGEMBANGAN KAWASAN}

Untuk mendukung upaya pemerintah dalam revitalisasi kawasan pecinan di Makassar, maka dilakukan pendekatan penciptaan kembali identitas kawasan sebagai kawasan yang signifikan sarat dengan kehidupan dan budaya etnis Cina. Strategi placemaking menjadi salah satu jawaban dalam mengembalikan dan menguatkan identitas suatu tempat tanpa menghilangkan karakter yang telah terbentuk.

Berdasarkan kajian literatur dan analisis persoalan fisik, maka diperlukan strategistrategi yang dibutuhkan dalam revitalisasi kawasan yang dijabarkan dari visi misi kawasan yang ada. Strategi-strategi yang akan diterapkan dalam konteks penciptaan kawasan menjadi kawasan yang lebih aktraktif adalah sebagai berikut: Meningkatkan dan memperbaiki kondisi fisik dalam kawasan. Peningkatan kualitas lingkungan dan perbaikan kondisi fisik dalam kawasan dibatasi akibat tingginya tingkat kepemilikan lahan. Pada kawasan umumnya didominasi oleh bangunan privat, baik pada daerah komersial maupun dalam kantung-kantung permukiman sehingga intervensi fisik yang mungkin dilakukan hanya terbatas pada penataan fisik bangunan lama dan yang telah hancur dengan penanganan renovasi ataupun rekonstruksi. Selain itu intervensi fisik juga dapat dilakukan pada ruang-ruang yang digunakan oleh publik, dalam hal ini koridor ruang jalan ataupun pada lahan-lahan yang tidak termanfaatkan. Strategi ini dilakukan untuk meminimalisir dampak perubahan atau hilangnya karakteristik fisik asli dan makna tempat dari kawasan Pecinan Makassar. Selain itu, juga dapat mendorong terciptanya jalur sirkulasi pejalan maupun kendaraan dengan kualitas lingkungan yang nyaman dan aman.

Menyuntikkan fungsi baru dan mengembangkan aktifitas-aktifitas yang menarik sesuai dengan karakter kawasan sebagai kawasan Pecinan. Penyuntikan fungsi baru pada kawasan dilakukan tidak terlepas dari konteks kawasan yang ingin mempertahankan dan menguatkan identitas kawasan sebagai kawasan pecinan yang diperkuat melalui penataan koridor Bacan. Fungsi-fungsi yang diberikan menjadi salah satu strategi yang dapat meningkatkan aktifitas dan interaksi masyarakat dalam kawasan yang kini sudah mulai ditinggalkan. Pengembangan fungsi-fungsi baru sebagai wadah kegiatan yang aktif dan aktraktif dalam menarik pengunjung sehingga dapat menjadi suatu pilihan yang bersifat rekreatif.

Melibatkan stakeholder dalam pengembangan kawasan. Upaya pengembangan kawasan pecinan dipengaruhi oleh stakeholder yang terlibat, seperti : pemerintah, pihak swasta (investor), dan masyarakat. Berikut keterlibatan stakeholder dalam upaya pengembangan kawasan adalah: Perbaikan infrastruktur kawasan 
(jalan, utilitas kawasan, dll) dilakukan oleh pemerintah dan penggunaannya dikelola oleh pemerintah kota Makassar. Memanfaatkan parkir pada kantung-kantung parkir dilaksanakan oleh pihak swasta (investor). Perbaikan street frontage (fasad muka bangunan) khususnya pada koridor jalan Bacan dilaksanakan oleh pemilik bangunan atau investor dibawah pengawasan pemerintah. Penataan fisik bangunan dengan suntikan fungsi baru pada bangunan yang hancur dan tidak dihuni dilakukan oleh pihak swasta (investor) dibawah pengawasan pemerintah dan masyarakat. Penataan fisik bangunan yang merupakan milik privat dilakukan oleh privat itu sendiri (masyarakat) dibawah pengawasan pemerintah dan pemberian keringanan berupa pajak atau pemberian insentif oleh pemerintah karena telah mendukung upaya pemerintah dalam pengembangan revitalisasi kawasan Pecinan sebagai suatu destinasi wisata. Diperlukan kerjasama oleh berbagai pihak dalam pengembangan kawasan dengan membentuk badan kerjasama perancangan, pengawasan, dan pengelolaan dalam peningkatan dan pengembangan kawasan oleh pihak pemerintah yang didalamnya terdiri dari perwakilan pihak swasta (investor), masyarakat, dan pemerintah itu sendiri.

\section{PENUTUP}

Revitalisasi kawasan merupakan upaya yang dilakukan dalam menghidupkan kembali kawasan pecinan Makassar. Revitalisasi tersebut tidak hanya pada perbaikan fisik tetapi didukung oleh peningkatan ekonomi, dan sosial sebagai upaya dalam mengembalikan atau menguatkan kembali identitas kawasan pecinan. Untuk mendukung upaya tersebut dibutuhkan suatu konsep atau strategi yang kontekstual dengan kondisi lahan kosong dan bangunan gudang yang terlantar sebagai kantung-kantung parkir. Penyediaan sarana kawasan. Pendekatan placemaking dapat menjadi satu strategi dalam menguatkan kembali dan mempertahankan karakteristik kawasan pecinan yang telah terbentuk di kota Makassar.

Berdasarkan hasil studi dikemukakan bahwa strategi placemaking pada kawasan pecinan kota Makassar memiliki 3 komponen yang dapat menjadi acuan dalam pengembangan kawasan, yaitu: Komponen Fisik .Ditandai dengan jejak fisik yakni adanya bangunan-bangunan tua berlanggam Cina (klenteng) dan ruko lama Cina yang berderet dengan menonjolkan elemen-elemen bangunannya, seperti penggunaan atap, material, dan ornamen lainnya pada kawasan yang terbentuk sekitar abad XIX, meskipun sebelumnya sejak abad XIV telah banyak orang Cina yang singgah dan berdagang di Makassar. Selain itu, juga terdapat bangunan kolonial. Komponen Fungsi dan Aktifitas Ditandai dengan adanya aktifitas etnis cina yang memiliki 'nyawa' pada koridor-koridor jalan. Komponen Citra/budaya Adanya makna budaya yang tetap dipertahankan dan memberikan warna tersendiri bagi etnis Cina.

Ketiga komponen tersebut kemudian dijelaskan masing-masing secara detail dalam elemen rancang kota. Elemen tersebut meliputi: fungsi dan aktifitas, bentuk dan tata massa bangunan, intensitas bangunan, sirkulasi kendaraan, parkir, dan sirkulasi pejalan. Berdasarkan pembahasan yang telah dilakukan didapatkan bahwa kawasan pecinan kota Makassar masih berpotensi untuk dikembangkan dari adanya jejak fisik yang tersisa, komunitas yang hidup dalam kawasan, fungsi dan aktivitas yang menarik, serta kegiatan keagamaan dan kebudayaan yang masih dipertahankan.

\section{DAFTAR PUSTAKA}

Carmona, M., et al. 2003. Public Places Urban Spaces - The dimensions of Urban Design. London: Architectural Press.

Effendy, Muslimin A.R. 2004. Tionghoa Makassar di Tengah Pusaran Sejarah, dalam Kontinuitas dan Perubahan Dalam Sejarah Sulawesi Selatan. Yogyakarta: Ombak.

Garnham, H.L. 1985. Maintaining The Spirit of Place: A Process For The Preservation of Town Character. Arizona: PDA Publishers Corporation. 
Gehl, J. 1987. Life Between Buildings: Using Public Space. New York: Van Nostrand Reinhold Company Inc.

Krier, R. 1979. Urban Space. New York: Rizzoli International Publications.

Montgomery, J. 1998. Making A City: Urbanity, Vitality, and Urban Design. Journal of Urban Design, Vol. 3 No. 1: 93-116.

Richardon, J.M. 1995. Chinatown Historic District. Singapore: Urban Redevelopment Authority.

Rutz, Werner. 1987. Cities and Towns in Indonesia. Stuttgart: E. Schweizerbart Science Publishers.

Shirvani, H. 1985. Urban Design Process. NewYork: Van Nostrand Reinhold Company Inc.

Sukatanya, Y., dan Monoharto, G. (ed.). 2000. Makassar Doeloe Makassar Kini Makassar Nanti. Makassar: Yayasan Losari Makassar.

Tiesdell, S., Oc, T., dan Heath, T. 1996. Revitalizing Historic Urban Quarters. Oxford: Architectural Press 
